\title{
An Early Parallel to the Hippocratic Oath
}

\author{
By Charles Singer, Par (Cornwall)
}

In all Greek medical literature no document has been more discussed than the so-called Oath. Among the most debated elements in it are the ethical clauses. These forbid (1) inducing abortion; (2) giving poison on the patient's request; (3) the unequal treatment of bond or free, male or female; (4) unchastity; (5) revelation of matters observed or heard during professional attendance.

(1) In the Græco-Roman world abortion had no criminal implication. How could it have in a society which exposed its unwanted infants? Moreover a method of inducing abortion is in fact described in the Hippocratic Collection.

(2) The taking of poison, under medical guidance by those hopelessly sick, was recognised in antiquity. It was a regular and advised practice, specially among the Stoics. Suicide did not involve in antiquity the moral disapproval and legal obstacles that are attached to it in modern society.

The difference in the ancient attitude to (3) and (4) from that of a modern society of historic ally Christian origin extends to the ethical bases of the two societies. Discussion of these bases is not necessary here and would not further our enquiry.

For reasons such as these some, and I among them, have sometimes thought there may be some Christian influence in that form of the Oath that has come down to us. No pre-Christian writer refers to these clauses. Galen, who died in 201 A.D., never mentions the Oath at all. Since his writings cover every aspect of medical activity, it might reasonably be conjectured that the Oath was an ancient formula which was disregarded in Galen's time, and that it was revived, modified, and came into new popularity, when given a Christian tinge, with the rise of Christian influence in the third century of our era.

This view had difficulties of its own. Notably the invocation to AscLEPIos had to be explained. How could this survive Christian influence? To that certain considerations might be rejoined. Firstly it was not suggested that it was a fully Christian formula but one the asperities of which had been softened under pervasive but indirect Christian influence. Secondly that of all the pagan deities AscLepios was the least unacceptable to Christian thought. So much was this so that he had at times been identified with one 
of the Christian sacred figures. His name is often used in Latin Christian documents and there are conventional representations in which the person of CHRist has merely replaced that of Asclepios. It was for such reasons as these that I myself felt that the Oath, in the form in which it has survived, had been to some degree Christianised.

This view became improbable, and perhaps untenable, with the publication by Professor Ludwig Edelstein of his important work on the Oath issued, very appropriately, as the first 'Supplement' of the 'Bulletin of the History of Medicine' under the editorship of Henry E. Sigerist. EdelSTEIN's careful investigation showed that the Oath is probably throughout a Pythagorean document and that it may well be of as early as the fifth century B. c. It still remains, however, an almost unique document with very few parallels in ancient literature. To one such parallel, which has remained unnoticed in this connection, I would now draw attention.

It is needless to consider here the very familiar text of the Oath itself. It is enough to recall that it divides naturally into four parts, each of which presents its own problems. I do not propose here to discuss these problems but merely to remind the reader of a few of them.

I. Invocation. This involves in effect only Asclepros for the two other named deities, Hygieia and Panaceia, have hardly any existence independent of him. With rare exceptions they are little more than his 'attributes'. After the family of Asclepios "all the gods and goddesses" are thrown in, as a matter of courtesy. It is evident that the mind of the invocant is occupied by Asclepios. This formula of naming a specific god and adding "all the gods and goddesses" is a regular convention for invocations, especially in the later pre-Christian centuries. In the mind of many educated Greeks "the gods" thus became more or less interchangeable.

II. Duty of the Physician to his Teachers. My parallel has little reference to this section. It suffices to recall that the Oath here involves some sort of closed association. This is not limited by any rite, as often in such societies, but merely by common agreement-something like Society, with a capital $\mathrm{S}$-in fact 'a gentleman's agreement' but nevertheless making very great demands on the invocant. The society is limited however by a written document, a syngraphe or contract, usually rather weakly translated into English as covenant.

III. Duty of the Physician to his Patients. In this section there is a series of undertakings. Those relevant here are: 
(a) Undertaking to give no deadly drug, even if asked, nor to take any share in such counsel.

(b) Undertaking not to give an arbortifacient.

(c) Undertaking to have no sexual relations with any member of a household where the physician is called.

(d) Special inclusion under (c) of bond and free, male and female.

(e) Pledge of silence on all things in the lives of those seen in the course of treatment "which ought not to be blabbed abroad".

IV. Penalty. This is purely moral and involves only 'loss of face'.

Toward the end of the second century B.c. or perhaps at the beginning of the first-say about 100 B. c.- a private shrine to the goddess AgDistis was built at Philadelphia in Lydia. That city had been founded only about fifty years earlier and was part of the Attalid Empire based on Pergamum as capital. It shared the Pergamenian culture as a remote provincial town. AgDistis was a mother-goddess whose cult was widely spread in Anatolia, Egypt, and even in Attica, from the third century B.c. onward. Such a mother-goddess, under various titles, is characteristic of the numerous Anatolian cults of the time. She is often associated with a male deity, sometimes as Asclepios, but more often under other names. Generally her consort is subordinate but sometimes AgDistis is associated with Zeus. On her shrine at Philadelphia is the following inscription:

'Let men and women, slave and free, when coming into this shrine swear by all the gods that they will not deliberately plan any evil guile, or baneful poison against any man or woman; that they will neither know nor use harmful spells; that they will neither turn to nor recommend to others nor have a hand in love-charms, abortives, contraceptives, or doing robbery or murder; that they will steal nothing but will be well-disposed to this house, and if any man does or purposes any of these things they will not keep silence but will reveal it and avenge. A man is not to have relations with the wife of another, whether a free woman or a married slave, or with a boy, or with a virgin, or to counsel this to another ... Let not woman or man who do the aforementioned acts come into this shrine; for in it are enthroned mighty deities, and they observe such offences, and will not tolerate those who transgress their commands... These commands were set up by the rule of AGDisTis, the most holy guardian and mistress of this shrine. May she put good intentions in men and women, free and slave alike, that they may abide by what is here inscribed; and may all men and women who are confident of their uprightness touch this 
writing, which gives the commandments of the god, at the monthly and at the annual (?) sacrifices in order that it may be clear who abides by them and who does not. O Saviour Zeus, hear our words, and give us a good requital, health, deliverance, peace, safety on land and sea.' (Italics added by author of article.)

To what extent Pythagorean elements may be traceable in the cult of AgDistis and the survival of such distinguishable elements as late as 100 B.c. may well be a subject for enquiry. The similarity of some of the wording of the ethical elements in the AgDISTIS inscription to those of the "Hippocratic" Oath are, in any event, self-evident. To read them will leave that document less isolated than it was before.

The Text of the Agdistis inscription is given in W. Dittenberger's Sylloge Inscriptionum Graecarum, Edition 3, no 985. I have reproduced the translation of Professor A.D. Nock of Harvard from his work Conversion: The Old and the New in Religion from Alexander the Great to Augustine of Hippo, Oxford 1933, by whose permission and that of the Clarendon Press this is here printed. I am also grateful to my colleague, Professor V. G. ChIlde, for having drawn my attention to this passage.

\title{
On Galen's Pneumatology
}

\author{
By Owsei Temkin, Baltimore
}

As is well known, GaLen believed that the soul had three divisions to each of which a special anatomical seat could be allocated. He devoted his work On the dogmas of Hippocrates and Plato to the proof that the divine soul with which man thinks dwells in the brain, while passion (especially wrath) and desires have their principles in the heart and liver respectively. To this psychological division corresponds a physiological one. The brain

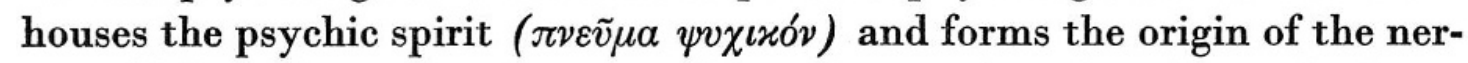
ves which conduct sensations as well as voluntary impulses. From the heart the arteries containing blood and vital spirit ( $\pi \nu \varepsilon \tilde{v} \mu \tilde{\alpha} \zeta \omega \tau \iota x o ́ v)$ depart, regulating the innate heat of the body and nourishing the psychic pneuma. The liver ist the main organ of hematopoiesis and also the origin of the veins which carry nourishment to the rest of the body. 